\title{
INFLUENCE OF WORLD COMMODITY PRICES ON THE DYNAMICS OF INCOME OF EXPORTING COUNTRIES OF NATURAL RESOURCES UNDER GLOBALIZATION
}

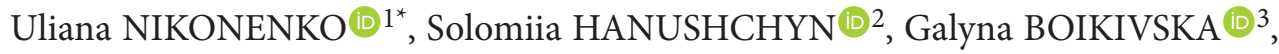 \\ Yuliia ANDRIICHUK ${ }^{10}$, Vasyl KOKHAN ${ }^{5}$ \\ ${ }^{1}$ Faculty of Media Communications and Entrepreneurship, Ukrainian Academy of Printing, Lviv, Ukraine \\ ${ }^{2}$ Department of Psychology and Management, Lviv State University of Internal Affairs, Lviv, Ukraine \\ 3, ${ }^{4}$ Department of Human Resource Management and Administration Lviv Polytechnic National University, \\ Lviv, Ukraine \\ ${ }^{5}$ National Academy of Ground Forces, Lviv, Ukraine
}

Received 02 March 2020; accepted 28 April 2020

\begin{abstract}
A feature of modern globalization processes is their vulnerability to the volatility of short-term capital flows, which, combined with the growing volatility of commodity prices, have created serious difficulties for the economic policies of commodity-oriented countries. Therefore, the study of the impact of world commodity prices on the dynamics of economic growth of countries with commodity exports and the development of an appropriate methodology based on modern economic and mathematical tools is an urgent task. The purpose of the study is the impact of volatility and the level of world commodity prices on income dynamics (GDP and industrial production) using three groups of countries with different levels of economic development as an example. Functional dependencies were studied for three groups of countries: industrial countries exporting raw materials, countries - commodity exporters of low income and commodity countries of the former Soviet Union. The analysis is based on quarterly data for the period 1980-2018 using the Two-Step Least Squares (2SLS) method. We developed a methodology for the economic and statistical analysis of the functional dependencies of the commodity economy, which provides for the simultaneous accounting of the level of world commodity prices and their volatility, allows us to empirically evaluate the mechanisms of the macroeconomic influence of commodity prices on the dynamics of economic growth, primarily income (GDP and industrial production). It has been established that rising world prices for raw materials improves the dynamics of GDP and industrial production of countries exporting primary resources, while the consequences of high volatility of price indices are predominantly negative. If the impact on the economic growth of the exporting countries of raw materials of individual price indices coincides, then the corresponding estimates for volatility can differ significantly.
\end{abstract}

Keywords: commodity exporting countries, world commodity prices, volatility, economic growth, income, gross domestic product (GDP), industrial production.

JEL Classification: E31, E37, O47, Q33.

\section{Introduction}

As the experience of recent decades shows, the deepening globalization processes are accompanied by significant instability in the dynamics of economic growth (around an uptrend) and increased volatility of world prices for raw materials, making an unambiguous effect on the economies of commodity exporting countries. Since the beginning of the last decade, there has been a rapid increase in world commodity prices, which had no analogues in the post-war history, but subsequently there was an equally stunning drop in commodity prices (during the financial crisis of 2008-2009), which, however, was quickly changed by the restoration of the price speakers. After several years of high price "plateaus" for most commodities, a significant decline in price indices began in the summer of 2014. It is difficult to argue that the high volatility of world prices for raw materials could not but affect the functioning of the world economy in general and the economic situation in exporting

${ }^{*}$ Corresponding author. E-mail: uliana_nikonenko@i.ua 
countries in particular. In this context, the choice of research topic is quite natural and relevant.

Today, the fact that modern globalization processes are vulnerable to the volatility of short-term capital flows, which, combined with the growing volatility of raw material prices, has created serious difficulties for the economic policies of countries with a commodity orientation, is very relevant. The main problem today is to determine the significance of the impact of world commodity prices on the economic development of exporting countries of raw materials.

The purpose of the study is the impact of volatility and the level of world commodity prices on income dynamics (GDP and industrial production) using three groups of countries with different levels of economic development as an example.

Assessing the significance of the influence of world commodity prices on the dynamics of economic growth requires a thorough study using statistics over a wide time range.

To study the effect of volatility and the level of world prices for raw materials, we use the two-step least-squares method, improved in this paper, which allows us to simultaneously determine the influence of these two parameters on the dynamics of economic growth.

Thanks to mathematical methods, we study the impact of global commodity price indices, including the general commodity price index, agricultural commodity price index, food price index, metal price index and crude oil price index on income dynamics (GDP and industrial production) in commodity-type economies in both dimensions - level and volatility.

The empirical research methodology includes methods of grouping, abstracting, comparing, theoretical generalization, and regression analysis. Our study was carried out using quarterly data for the period 1980-2018.

The novelty of the study lies in the development of a methodology for economic and statistical analysis of the functional dependencies of the commodity economy, providing for the simultaneous consideration of the level of world prices for raw materials and their volatility. The proposed methodology makes it possible to empirically evaluate the mechanisms of the macroeconomic influence of commodity prices on the dynamics of economic growth, primarily income (GDP and industrial production).

\section{Literature review}

Empirical evidence of the long-term impact of raw materials on economic growth is ambiguous. So in the 19801990s, the belief that the availability of natural resources slowed economic growth prevailed (Gylfason, Herbertsson, \& Zoega, 1999; Sachs \& Warner, 1995, 2001). For example, Auty (2001) demonstrated that large commodity economies such as Russia, Nigeria or Venezuela had a lower GDP growth rate than many countries without natural resources (Japan, South Korea, Hong Kong or
Ireland). The concept of "resource curse" or "excess paradox" has spread, which linked income stagnation to trade protectionism, macroeconomic instability, the spread of corruption, and a short-term decision-making horizon in economic policy. An excess of natural resources can provoke rather diverse effects from low budget deficits and high living standards in "weak" institutions and a slowdown in economic growth (Nikonenko, 2014, 2019).

In a recent study according to 1980-2010, signs of a resource "curse" have been identified for 43 developing countries (Emara, Simutowe, \& Jamison, 2015). This mainly concerns countries with energy exports, which are also characterized by institutional problems. For the United States, it was found that the oil and gas boom is accompanied by a significant increase in wages and short-term production growth at the regional level (Alcott \& Keniston, 2016). The "purity" of the results is that estimates for the United States are deprived of a possible dependence on the institutional factor.

However, more recent studies show a favorable relationship between comparative advantages in the commodity sector and economic growth (Brunnschweiler, 2008; Lederman \& Maloney, 2007; Raddatz, 2007; Rosser, 2006; Sylkin et al., 2019). It is difficult to argue the inverse relationship between income and demand for raw materials within a particular country, but in a globalized economy, excess production over demand can be offset by export. An example is Norway, where oil and natural gas exports have dominated for years, as well as Australia, Canada, Finland and New Zealand. With an increase in income, the relative predominance of raw materials in production and export decreases, but such examples in the Scandinavian or Anglo-Saxon countries are combined with a much larger number of negative examples in Africa and Latin America (Bacha \& Fishlow, 2011).

Arezki and Nabli (2012) showed that resource-rich countries are characterized by greater macroeconomic instability. As van der Ploeg and Poelhekke (2007) found, income volatility reduces economic growth and significantly weakens the incentive effect of high commodity prices. Aghion and Banerjee (2005) have empirically confirmed that excessive volatility worsens income dynamics. A similar result was obtained for 92 countries with different income levels and OECD countries, as well as for a group of African countries, mainly exporters of raw materials (Romero-Avila, 2009).

Recently, the issue of analyzing export dynamics in various countries has been actively investigated. For example, Carrere and Strauss-Kahn (2012) conducted research on export dynamics in developing countries.

One can also find an analysis of the dynamics of exports and imports using general methods of analysis (Hossain, Haseen, \& Jabin, 2009).

Ischuk and Tkach (2020) using the method of synthesis and analysis, analyzed the dynamics of exports for countries of Eastern Europe. However, in our opinion, to study and analyze the dynamics of exports and study 
the impact of prices on export dynamics, new, more effective methods should be applied, in particular, the 2SLS method.

The short-term correlation between the rise in prices of raw materials on world markets and economic growth is found for these 72 commodity economies for the period 1985-2013 (McGregor, 2017), 94 countries for the period 2004-2008 (Jawaid \& Waheed, 2011), 38 poor and emerging markets (Schmitt-Grohe \& Uribe, 2018), 18 emerging markets for the period 1990-2004 (Cakir, 2009), low-income countries (Raddatz, 2007), African countries (Houssa, Mohimont, \& Otrok, 2015), Latin America (Gruss, 2014) and small open economies in general (Kose, 2002). A similar dependence was obtained for India (Jawaid \& Raza, 2013), Malaysia (Wong, 2004), Russia (Ito, 2012), Chile and Uruguay (Trofimov, 2018). In general, such a situation only confirms the importance of choosing the specification of the statistical model, and above all, taking into account only the most important (or system) functional relationships.

Despite a fairly large number of scientific papers examining the dependence of the economic growth of exporting countries on the dynamics of world commodity prices, there are not enough such estimates not only for countries specializing in the production of goods with low added value, but also for certain groups of countries, primarily the former Soviet Union.

\section{Research model}

To assess the impact of world commodity prices on the dynamics of income (GDP and industrial production) of individual countries, we used the following statistical model:

$$
\begin{aligned}
& \Delta \ln Y_{t}=\alpha_{0}+\sum_{i=1}^{n} \alpha_{i} \Delta \ln Y_{t-i}+ \\
& \beta_{1} \ln P_{t}+\beta_{2} \text { pvar }_{t}+\gamma_{1} \Delta \ln Y_{t}^{*}+\varepsilon_{t},
\end{aligned}
$$

where $Y_{t}$ is income (index, $2010=100$ ), $P_{t}$ is one of the world commodity price indices (index, $2005=100$ ), pvar ${ }_{t}$ is the conditional variance of the selected world commodity price index, $\alpha_{0}$ is a constant, $\alpha_{i}$ is the selected macroeconomic index with $i$-lag, $\beta_{1}$ is an estimate of the impact of the commodity price index, $\beta_{2}$ is an estimate of the impact of the volatility (instability) of the commodity price index, $\gamma_{1}$ is an estimate of the income index abroad, $\varepsilon_{t}$ is a stochastic factor.

It is assumed that the first differences in the logarithms of the income indicator depend on their own lag values, the values of one of the indices of world prices for raw materials and its volatility and income abroad (formula (1)). Although empirical studies predominantly use the terms of trade indicator (TOT - "term of trade"), the use of commodity indices has significant advantages, because there are no vulnerabilities in various biases of the statistical impact assessment (biases) and possible endogeneity (Fernández, Schmitt-Groh, \& Uribe, 2017; Shousha, 2016).
As can be seen from the survey of empirical studies, one can expect both the increase in GDP and absolutely opposite effect from an increase in world prices for raw materials, primarily in economies with weak institutions. The degree of development of the financial market has its own influence. Since the estimates for short-term dependencies are mostly favorable, one can hope for a similar effect for the studied countries $\left(\beta_{1}>0\right)$. It is more complicated with industrial production, because the argument about deindustrialization implies "crowding out" industry by improving TOT in the primary sector. On the other hand, industrial production can be stimulated by increasing demand in the economy of a country exporting raw materials. This means a lack of clear predictions regarding the consequences of rising costs of raw materials on world markets $\left(\beta_{1}<>0\right)$.

Although in some cases a favorable relationship was obtained (Jawaid \& Waheed, 2011), the dependence on commodity price volatility is mostly negative (Cavalcanti, Mohaddes, \& Raissi, 2012; Bodart, Candelon, \& Carpantier, 2012; Moreira, 2014), $\beta_{2}<0$. In some cases, there are differences in the context of individual commodities. For example, it was found that the volatility of crude oil prices has a negative effect on GDP, but this is not the case for food prices and metals (Hachula \& Hoffmann, 2015).

Dependence on income abroad is usually favorable, because it means an increase in export demand, regardless of the price factor $\left(\gamma_{1}>0\right)$. In both cases - the volatility of commodity prices and income abroad - there is no reason for an asymmetric effect on GDP and industrial production.

The use of several commodity indices is justified in terms of the different dependence of individual macroeconomic indicators on changes in the prices of various commodities. For example, global metal prices can determine the dynamics of GDP, while agricultural commodity prices can determine private consumption (Raddatz, 2007). This involves accounting for the value of several commodities.

\section{Empirical results}

\subsection{Data and model specification}

The analysis was carried out using quarterly data for the period 1980-2018. In the context of several indicators: $\mathrm{PCOM}_{t}$ is the general price index for commodities $(2005=100)$, PRAWt is the price index for agricultural raw materials $(2005=100), P F O O D_{t}$ is the price index for food products $(2005=100), P M E T A L_{t}$ is the price index for metals $(2005=100), P O I L_{t}$ - crude oil price index $(2005=100)\left(P R A W_{t}\right.$ agricultural raw materials price index including the cost of wood, cotton, wool, rubber and leather; the $P F O O D_{t}$ food price index takes into account the value of cereals, vegetable oil, meat, seafood, sugar, bananas and orange juice; $P M E T A L_{t}$ metal price index - aluminum, copper, nickel, tin, lead, uranium, zinc and iron ore. The POIL $t_{t}$ Crude Oil Price Index is the average cost 
of the Brent, West Texas Intermediate and Dubai Fateh grades) using the two-step least squares method (2SLS).

Functional dependencies were studied for several groups of countries: 1) industrial countries exporting raw materials (Australia, Canada, New Zealand, as well as Portugal and South Korea), 2) countries - raw material exporters of low-income (Argentina, Brazil, Colombia, Mexico, Chile, Uruguay, Indonesia, Malaysia, Thailand, South Africa, Turkey), 3) countries of the former Soviet Union (Belarus, Georgia, Kazakhstan, Moldova, Russia, Ukraine). Although only selected countries in Latin America (except Mexico) meet the formal criteria of a commodity-exporting country - the share of raw materials in total exports is more than 60\% (UNCTAD, 2016), in addition, expanding the list of the studied groups of countries is expedient for several reasons.

Firstly, it is interesting to compare the dependence on world prices for raw materials of various segments of the world economy. Secondly, Australia and Canada are major exporters of mineral and agricultural raw materials, while Portugal exports agricultural products and food, while South Korea exports metals (zinc, tin) and metal products. Thirdly, the selected countries of Southeast Asia, South Africa and Turkey also differ in a significant share of raw and semi-raw goods in exports, although they cannot be considered raw in the full sense. In particular, this concerns Turkey, which is characterized by a developed industry and a significant export of metallurgical and agricultural products (this likens Ukraine). Furman (2018) claims that in Turkey, manufacturing accounts for $81 \%$ of GDP, and machine building takes 6th place in terms of production of machinery and equipment in Europe, with a $90 \%$ average localization level and high technological effectiveness of production. At the same time, the production of metallurgical products increased in 2007-2016. By $42.4 \%$ (while the average annual increase in domestic steel consumption in the country was $11.4 \%$ - the best indicator in the world). By the level of agricultural production, the country occupies the 6th place in the world and the 1st in Europe. According to the HTS classification, in 2017, the main export goods were vehicles and their components (9\%), metal products (9\%), precious metals $(7 \%)$, electrical equipment (5\%), clothes and shoes (4\%) of materials (3,5\%), mineral fuel (3\%)). Finally, almost all of the post-Soviet countries can be classified as exporting countries of raw materials or semi-raw materials (metal products).

The choice made is consistent with the logic of empirical research, which provides for the dependence of economic growth on world commodity prices not only for exporting countries or countries specializing in the production of low value added goods, but also aims to confirm (or refute) the weight of price dynamics in commodity markets for certain groups of countries, primarily the former Soviet Union.

In our opinion, the practical value is created not so much by comparing the structure of the Ukrainian economy with the EU countries or the G-7, which is quite widespread in domestic literature (Vashkiv, 2017), as with the exporting countries of low-income raw materials, primarily it is about the largest countries in Latin America (Argentina, Brazil, Mexico, Chile), as well as South Africa and Turkey. In particular, recently, for some Ukrainian economists, Turkey was an example of vigorous industrialization and successful reforms (Furman, 2018), but the realities of the last financial crisis in this country (summer 2018) forced to reconsider (According to Butko (2018), for a long time Turkey's successes in the media (including Ukrainian ones) were usually described in complementary tones, and therefore the next financial crisis of August 2018 was completely unexpected, although for the period 1980-2017. Rapid ups have changed more than once. Comparison with the countries of the former Soviet Union allows to see better the common features and differences of a fundamental nature (if there are any). On the other hand, it is hardly advisable to focus on the characteristics of such commodity-exporting countries (in the full sense of this category), such as Angola, Botswana, Equatorial Guinea or Mali, which are completely dependent on mono-export of raw materials (In total, 95 out of 141 developing countries receive more than 50\% of export earnings from the export of raw materials (UNCTAD, 2012)).

Latin American countries are of great interest from the point of view of the widespread assumption that in economies with comparative advantages in the commodity sector, macroeconomic and institutional factors are more influenced by the dynamics of economic growth rather than raw materials (Poppe, 2016). Also, these countries are usually referred to those that suffer from the "resource curse". The only exception is Chile, while in the countries of Southeast Asia there are more such positive examples, in particular Malaysia and Thailand.

A separate aspect of Latin American experience is approaches to export diversification. If Chile supplemented the export of one main product, copper, with the export of fruits and vegetables, Argentina expanded the range of agricultural products (Dovgan, 2015). On the other hand, Mexico - an exporter of oil and agricultural products - has gradually moved to the export of machinery and vehicles (this was facilitated by foreign investment). Brazil remains a significant exporter of agricultural products and steel, and more recently, crude oil, but at the same time exports more and more industrial goods. Colombia combines the Chilean pattern with an increase in light industry production such as Southeast Asian countries. Uruguay remains an exporter of agricultural raw materials (more than 70\% of the total), but has recently been trying to complicate exports through the use of modern technologies in the agricultural sector and the processing industry (Sandonato \& Willebald, 2018).

Among the countries of the former Soviet Union, all countries without exception can be considered as raw materials in the broad sense (taking into account low-tech 
metallurgical production). The Russian economy fully embodies the raw material orientation. Revenues from raw materials account for $50 \%$ of federal budget revenues, provide $100 \%$ of revenues to the Reserve Fund and the National Welfare Fund, as well as $60-70 \%$ of foreign currency receipts (Danilenko, 2014). Despite the declared course towards technological modernization, there are no significant shifts for the better. Kazakhstan also belongs to the countries with a standard commodity orientation, where oil and gas are gradually dominating in the export structure, and in exporting high-tech products it is significantly inferior to countries such as the Philippines, Mexico, and Malaysia.

\subsection{Results and discussion}

Estimates of the dependence of the GDP dynamics of individual exporting countries on the volatility (instability) of world commodity prices are rather contradictory (Table 1). If Australia is completely independent of the instability of price indices, then at the end of industrial countries, the corresponding dependence turned out to be significant and multidirectional for both individual countries and individual price indices. Instability worsens the dynamics of GDP in Canada and Portugal, while a stimulating effect was obtained for South Korea and New Zealand. The instability of the other two indices - $P R A W_{t}$ and $\mathrm{PFOOD}_{t}$ - retains a stimulating effect in New Zealand, but in Canada and Portugal, either the sign of the corresponding regression coefficient changes or its statistical significance is lost. It should be noted that increasing volatility in crude oil prices is harming economic growth in oil-producing Canada, while it is favorable for oil-importing countries such as South Korea and New Zealand.

In the largest countries of Latin America (Argentina, Brazil, Mexico, Chile), the instability of the general commodity price index does not affect the dynamics of GDP (the sign of the coefficient for $\mathrm{PCOM}_{t}$ is mostly negative), while in Thailand, Malaysia and South Africa the impact is clearly negative. Obviously, this applies to most countries of the former Soviet Union, including Ukraine and Russia. The instability of world raw material prices benefits only Turkey and Colombia, as well as Georgia. However, for most countries (Argentina, Brazil, Uruguay, Indonesia, Thailand, Malaysia, South Africa, Kazakhstan), a favorable dependence of GDP dynamics on the instability of world commodity prices appears when using the sub-index $P_{R A W}$ and $\mathrm{PFOOD}_{t}$. At the same time, the favorable dependence for Colombia and Turkey is lost, there are no changes for Georgia.

Like industrial countries, exporting countries (Argentina, Brazil, Indonesia, Mexico, Russia) do not have any benefit from the instability of world crude oil prices, while the opposite applies to importing countries (Colombia, Turkey, Georgia). However, in several importing countries (Malaysia, Thailand, South Africa, Belarus, Moldova, Ukraine) a negative effect of volatility in crude oil prices was revealed. For Ukraine, a significant inverse relationship between the volatility of the general commodity price index and the dynamics of GDP arises mainly due to the instability of crude oil prices, probably exacerbating the price effects for metal products and food products (corresponding negative coefficients lack statistical significance), while the instability of world prices for agricultural raw materials have no negative impact.

For most of the studied countries, earlier results were confirmed, excessive price volatility reduces the dynamics of economic growth and significantly weakens the stimulating effect of rising prices for raw materials. It is important to distinguish between the dependence of GDP dynamics on the instability of world prices for raw materials and their own instability, which can arise due to many other reasons that are not directly related to raw material prices, but this possibility is not critical for commodityexporting countries.

We have found that higher prices for raw materials on world markets mainly improve the dynamics of GDP, but such an effect can be traced at a statistically significant level only for 11 countries $\left(P C O M_{t}\right), 13$ countries $\left(P R A W_{t}\right)$ and 8 countries $\left(\right.$ PFOOD $\left._{t}\right)$. The increase in food prices is favorable primarily for low-income countries (Argentina, Brazil, Thailand, Malaysia, Russia, Ukraine), while industrial countries (Canada, Portugal, New Zealand) also benefit from higher prices for agricultural raw materials. The predominantly industrial countries, as well as Brazil, Kazakhstan, Russia and Ukraine, benefit from the rise in prices for metal products. In one of the countries, there was no negative dependence on the rise in crude oil prices on world markets, including Ukraine.

Estimates for industrial production as a whole confirm the nature of functional dependencies for GDP dynamics, but there are certain differences (Table 2). A more favorable dependence on world commodity prices appears in New Zealand, Mexico and Turkey. At the same time, the influence of price volatility is weakening in most countries, as was obtained for estimates of GDP (Table 1). In Australia, industrial production is independent of global food and metal prices. At the same time, in Chile, the dependence of industrial dynamics on world metal prices is becoming much more pronounced. In some countries (New Zealand, Turkey) the increase in prices for agricultural raw materials and food products does not affect the dynamics of GDP, but improves the dynamics of industrial production.

Compared with estimates for GDP, for industrial countries there is an increase in the dependence of $P I N D_{t}$ on income abroad. In low-income countries, the opposite is true, primarily in Brazil, Mexico, and Turkey. A similar feature is inherent in most countries of the former Soviet Union, including Ukraine, although the dependence of industrial production in Russia on income in eurozone countries is becoming stronger.

In general, the results obtained do not give reason to deny both hypotheses about the mechanisms of the relationship between an open economy and economic growth - based on changes in trade conditions or foreign 


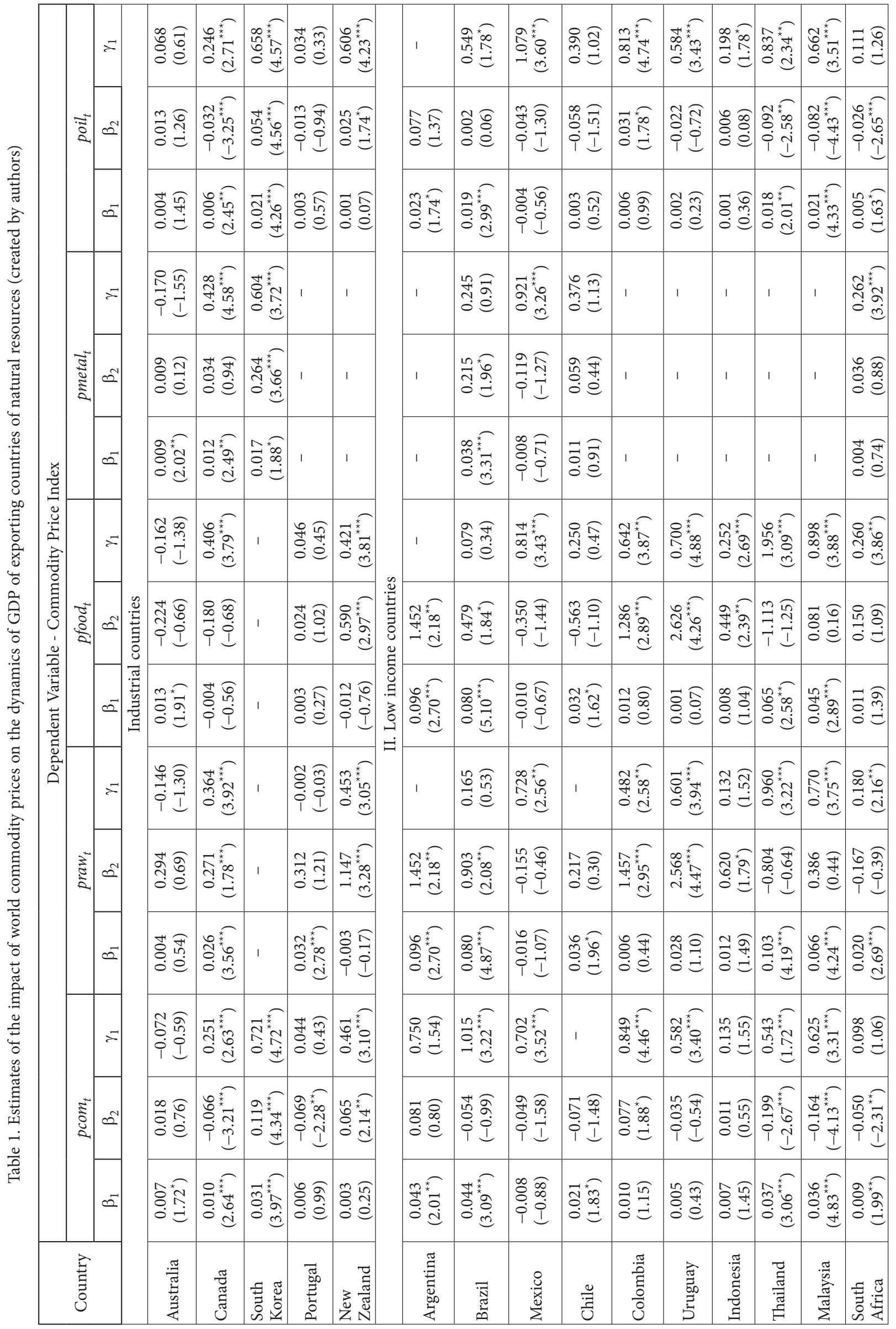


है

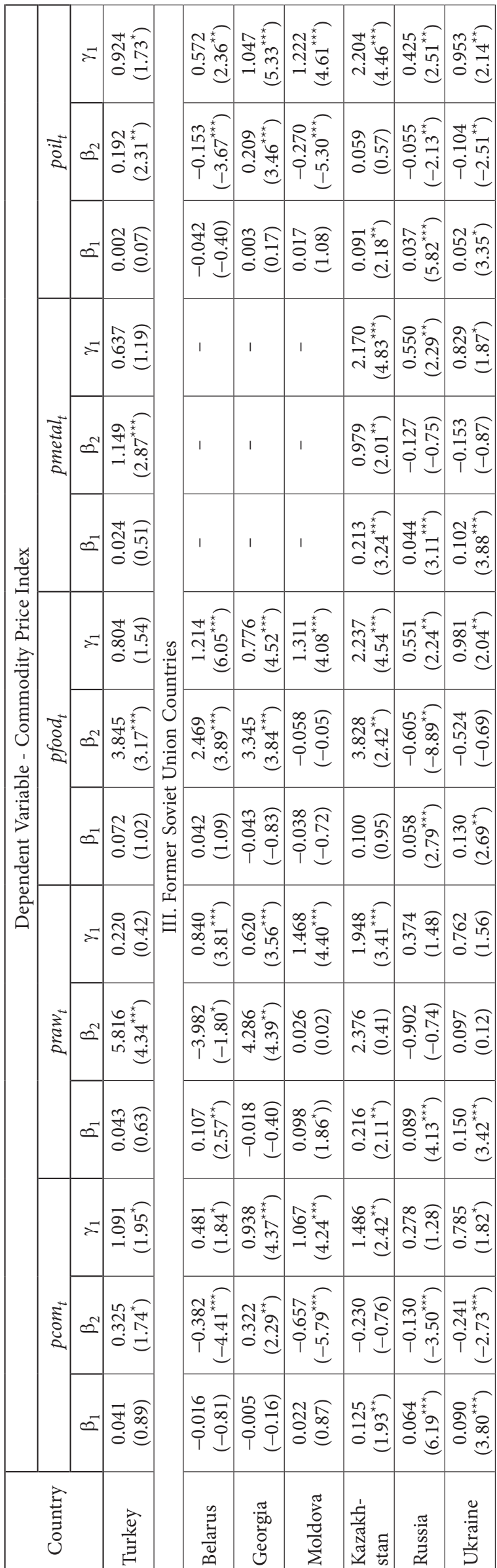




\begin{tabular}{|c|c|c|c|c|c|c|c|c|c|c|c|c|c|c|c|c|c|c|}
\hline & \multirow{3}{*}{ 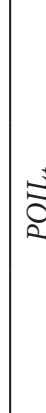 } & $\Sigma$ & 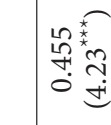 & 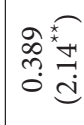 & 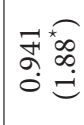 & 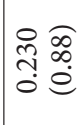 & 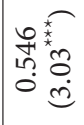 & & 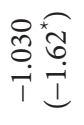 & 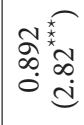 & 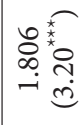 & 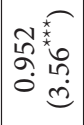 & 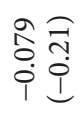 & & 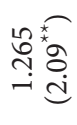 & 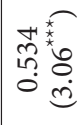 & 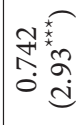 & 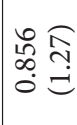 \\
\hline & & $\varrho^{2}$ & $\begin{array}{l}\overrightarrow{0} \\
0 \\
0 \\
0\end{array}$ & 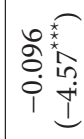 & $\begin{array}{ll}\vec{z} & \widehat{N} \\
0 & 0 \\
0 & 0 \\
1 & 1\end{array}$ & 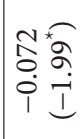 & $\begin{array}{ll}\widetilde{\delta} & \widehat{\sigma} \\
0 & \stackrel{i}{i}\end{array}$ & & 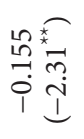 & 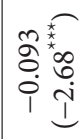 & 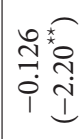 & 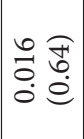 & 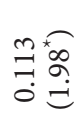 & & 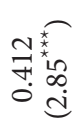 & 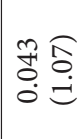 & $\begin{array}{ll}\infty & 0 \\
0 & 0 \\
0 & + \\
1 & 1 \\
1 & 1\end{array}$ & 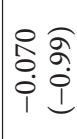 \\
\hline & & $a^{-1}$ & 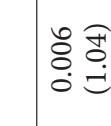 & 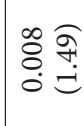 & 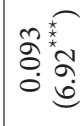 & 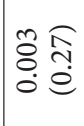 & 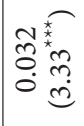 & & 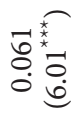 & 稂 & 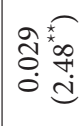 & 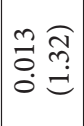 & 跣 & & 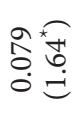 & $\begin{array}{l}\vec{\sigma} \\
\dot{0} \\
\dot{0}\end{array}$ & 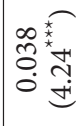 & 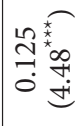 \\
\hline \multirow{3}{*}{\multicolumn{2}{|c|}{ : }} & 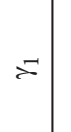 & רנ & 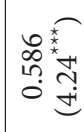 & 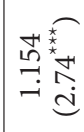 & 1 & 1 & & 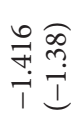 & 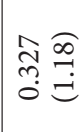 & 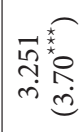 & 1 & 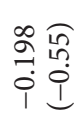 & & 1 & 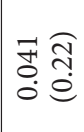 & 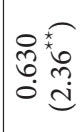 & $\begin{array}{ll}\infty & \approx \\
\infty & \approx \\
0 & \stackrel{0}{=}\end{array}$ \\
\hline & & $\varrho^{N}$ & $\begin{array}{l}8 \\
8 \\
0 \\
0 \\
i \\
1\end{array}$ & 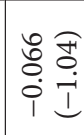 & 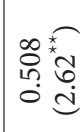 & 1 & 1 & & 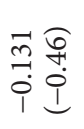 & $\begin{array}{ll}0 & 0 \\
\hat{0} & 0 \\
i & 0 \\
i & i\end{array}$ & 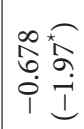 & 1 & 委 & & 1 & 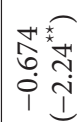 & 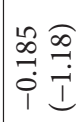 & 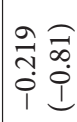 \\
\hline & & $\varrho^{-1}$ & $\begin{array}{ll}0 & 0 \\
8 & 0 \\
0 & 0 \\
1 & 1\end{array}$ & 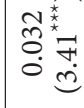 & 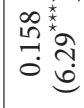 & 1 & 1 & & 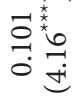 & 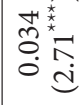 & 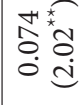 & 1 & 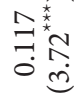 & & 1 & 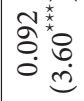 & 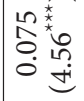 & 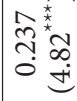 \\
\hline 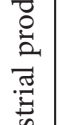 & \multirow{3}{*}{$\begin{array}{l}0 \\
8 \\
0 \\
\text { 1 }\end{array}$} & $\Sigma$ & 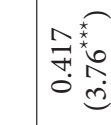 & 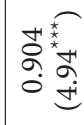 & 1 & 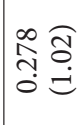 & 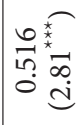 & & 桒蛋 & 종 & 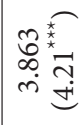 & 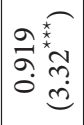 & 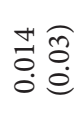 & $\mathscr{g}$ & 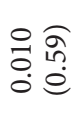 & 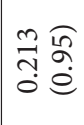 & 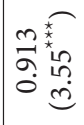 & 落 \\
\hline 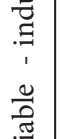 & & $\varrho^{2}$. & 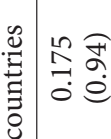 & 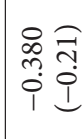 & 1 & 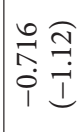 & $\begin{array}{ll}0 & \widehat{n} \\
\infty & 0 \\
0 & 0 \\
0 & 1 \\
1 & 1\end{array}$ & 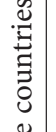 & 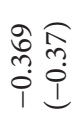 & 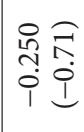 & 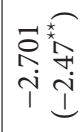 & 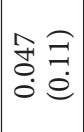 & 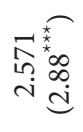 & 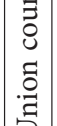 & 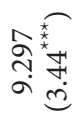 & 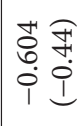 & 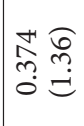 & 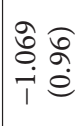 \\
\hline 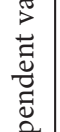 & & $=$ & 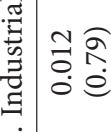 & 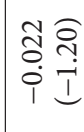 & 1 & 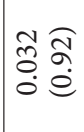 & 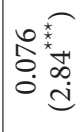 & 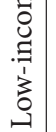 & 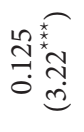 & 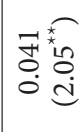 & 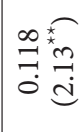 & $\begin{array}{ll}\hat{a} & \widehat{\sigma} \\
0 \\
0 & \stackrel{0}{0}\end{array}$ & 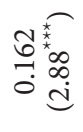 & 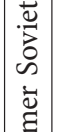 & $\begin{array}{ll}0 & 0 \\
0 & 0 \\
0 & 0 \\
0 & 0 \\
0\end{array}$ & 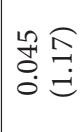 & $\begin{array}{l}\infty \\
\infty \\
0 \\
0 \\
0 \\
0 \\
0\end{array}$ & $\frac{n}{n}$ \\
\hline छ & \multirow{3}{*}{ 告 } & $\digamma$ & 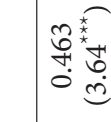 & 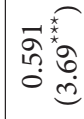 & 1 & 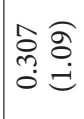 & 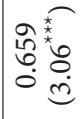 & & 六氐 & 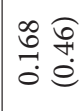 & 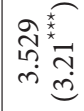 & 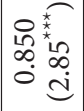 & 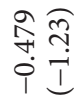 & 百 & 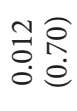 & 1 & 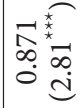 & $\begin{array}{l}\infty \\
\infty \\
\infty \\
0 \\
0\end{array}$ \\
\hline & & $\varrho^{2}$ & 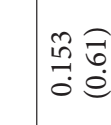 & $\begin{array}{l}8 \\
0 \\
0 \\
0 \\
0 \\
0\end{array}$ & 1 & $\begin{array}{ccc}9 & 0 \\
14 & 0 \\
0 & 0 & 0 \\
1 & 1\end{array}$ & $\begin{array}{lll}\vec{\infty} & \widehat{0} \\
0 & \infty \\
0 & 0 \\
i & 0 & 1 \\
1\end{array}$ & & $\begin{array}{l}n \\
0 \\
0 \\
0 \\
i \\
0 \\
0\end{array}$ & 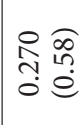 & 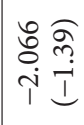 & $\begin{array}{ll}0 & 0 \\
0 & 0 \\
0 & 0 \\
0\end{array}$ & 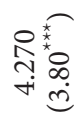 & & 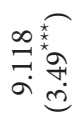 & 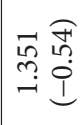 & 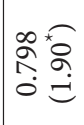 & $\begin{array}{ll}\vec{p} & \widehat{\delta} \\
0 & 0 \\
i & 0 \\
1 & 1\end{array}$ \\
\hline & & 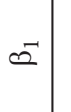 & $\begin{array}{l}\hat{8} \\
\stackrel{f}{0} \\
0 \\
0\end{array}$ & 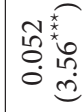 & I & 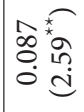 & $\begin{array}{l}8 \\
8 \\
0 \\
0 \\
0 \\
0\end{array}$ & & 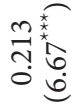 & 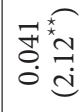 & 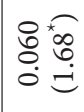 & 융 & 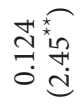 & & 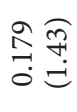 & 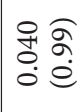 & 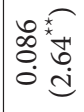 & 谣 \\
\hline & \multirow{3}{*}{$\begin{array}{l}5 \\
0 \\
0 \\
2\end{array}$} & $\Sigma$ & 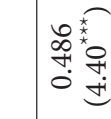 & 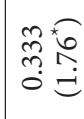 & 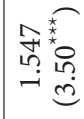 & 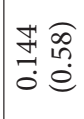 & 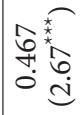 & & 栗 & 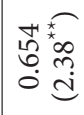 & 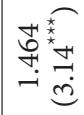 & 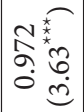 & $\begin{array}{l}\text { 옷 } \\
\text { : } \\
0\end{array}$ & & 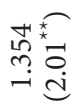 & 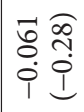 & 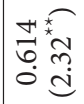 & 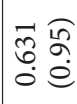 \\
\hline & & $\varrho^{N}$ & 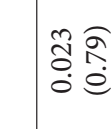 & 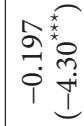 & $\begin{array}{l}\hat{\Omega} \\
\hat{n} \\
0 \\
0\end{array}$ & 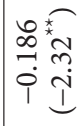 & 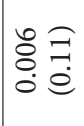 & & 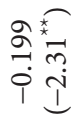 & 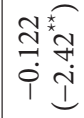 & 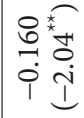 & 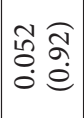 & 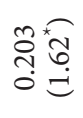 & & 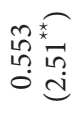 & $\begin{array}{ll}1 & \widehat{a} \\
0 & 0 \\
0 & 0 \\
1 & 1\end{array}$ & 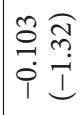 & $\begin{array}{ll}\overrightarrow{0} & \mathbb{6} \\
0 & 0 \\
0 & 1 \\
0\end{array}$ \\
\hline & & $a^{-1}$ & $\begin{array}{l}\hat{O} \\
0 \\
0\end{array}$ & 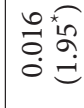 & 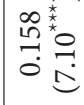 & $\begin{array}{l}0 \widehat{0} \\
0 \stackrel{n}{\varrho} \\
0\end{array}$ & 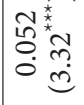 & & 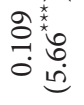 & 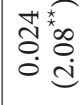 & 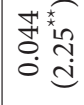 & 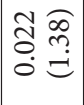 & 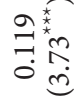 & & 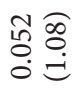 & 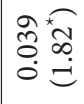 & 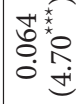 & $\mid$ \\
\hline & $\begin{array}{l}\widehat{E} \\
\text { 音 }\end{array}$ & & 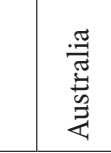 & $\begin{array}{l}\widetilde{\widetilde{J}} \\
\widetilde{\tilde{J}} \\
\tilde{J}\end{array}$ & 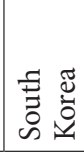 & 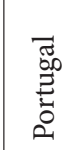 & ż & & $\begin{array}{l}\overline{\widetilde{N}} \\
\text { 馬 }\end{array}$ & $\begin{array}{l}\stackrel{0}{x} \\
\stackrel{\leftrightarrow}{\Sigma}\end{array}$ & 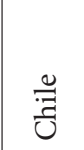 & 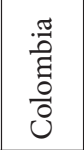 & $\begin{array}{l}\hat{\bar{y}} \\
\text { y } \\
\text { E }\end{array}$ & & 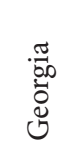 & 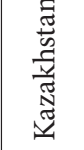 & 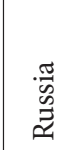 & 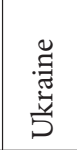 \\
\hline
\end{tabular}


trade volumes (this is indirectly determined by the dependence on income abroad), as emphasized in the work (Kehoe \& Ruhl, 2008). For commodity-exporting countries, both an increase in world prices for raw materials are equally favorable (somewhat simplified, this may serve as an approximate characteristic of improving terms of trade) and an increase in the income of trading partner countries. This is important, because a positive dependence of the dynamics of income on the terms of trade can only be a sign of short-term, while long-term influence can be negative. But there is no reason for such an intertemporal asymmetry depending on income abroad.

Of particular interest is the influence of world prices for raw materials on the dynamics of engineering products, which can be considered an indicator of deindustrialization (Table 3). In addition to Indonesia and Chile, rising global commodity prices (PCOMt) stimulate machine-building output, which denies the argument for de-industrialization. At the same time, higher volatility is becoming an obstacle in Chile, Indonesia, South Africa and Russia. But only for Colombia, Turkey and Russia, the favorable dependence of engineering on world prices for raw materials can be traced in the context of all price indices. In South Africa and Uruguay, a forum to stimulate engineering is the rise in crude oil prices. In one of the countries, no asymmetric influence of volatility was found at a statistically significant level for individual world commodity price indices.

For Ukraine, the stimulating effect is provided mainly through metal products and chemical products (its volumes directly correlate with crude oil prices). Odds for the $P R A W_{t}$ and $P F O O D_{t}$ price indices are positive, but they lack statistical significance. The volatility of world prices for raw materials does not have a decisive influence, although high coefficients for price indices for agricultural raw materials and food products, which lack statistical significance, provide for significant instability of production volumes in mechanical engineering in case of high instability of the corresponding price indices.

It is noted that in Ukraine there are no signs of stimulating the production of the food industry $\left(I N D F O O D_{t}\right)$ due to the increase in world prices for commodities, including food, and in the specification there is an inverse relationship with prices for agricultural raw materials. For an economy with comparative advantages in the agricultural sector, this indicates unused opportunities. The effect of price volatility is positive, but it just shows up in the specification with $P R A W_{t}$. Unlike estimates for GDP and industrial production, there is no stimulating effect from increased income abroad (EU countries), and in specifications with $P R A W_{t}$ and $P S O Y_{t}$, feedback becomes statistically significant.

In most of the studied countries with commodity exports, engineering products depend on income abroad, especially in Ukraine and Chile. Dependence on the trading partner countries has not been identified for Indonesia and Turkey, which means both a greater focus on the domestic market and the weakness of the "learning by doing" (LBD) process. On the other hand, favorable price effects in foreign trade can be considered a sign of increased labor productivity as a factor in the growth of production volumes.

Since in one of the countries there was no feedback between world prices for raw materials and the dynamics of economic growth, including engineering, in the group of studied countries with high and low income there is no threat of a "resource curse", including Ukraine. But in the indicated group of the studied countries, the real obstacle is the volatility of world prices for raw materials. Also, the formation of a competitive non-resource sector can be affected by difficulties with the redistribution of income or the institutional characteristics of countries exporting raw materials.

Comparing one's own study with the results of those who also used pebbles of the model to assess the influence of certain phenomena on changes in the dynamics of GDP, production, etc., we can say that there are cases (Araujo, 2016; Perez Fofero \& Servan, 2016) when an assessment was made using models, not taking into account those indicators and indices that accurately describe commodity prices, the specifics of countries exporting natural resources, etc. One of the features of our study is the application of the Two-Step Least Squares method.

\section{Conclusions}

A study and analysis of the impact of world commodity prices on income dynamics in exporting countries of natural resources was carried out using the developed methodology. As a result of the study, we used a statistical model to assess the impact of world commodity prices on income dynamics.

Based on the proposed methodological approach to the study and assessment of the impact of world commodity prices on the dynamics of income (GDP and industrial production), it was found that the growth in world commodity prices has a positive effect on the dynamics of the GDP of exporting countries of primary resources (this result can be seen at a statistically significant level in 12 out of 22 studied countries of the three groups), while the consequences of high volatility of commodity price indices are mostly negative (excessive price volatility reduces the dynamics of economic growth and significantly weakens the stimulating effect of rising prices for raw materials). A favorable relationship between the volatility of world commodity prices and the dynamics of GDP was obtained only for South Korea, New Zealand, Colombia, Turkey and Georgia. If the impact on the economic growth of the exporting countries of raw materials of individual price indices coincides, then the corresponding estimates for volatility can differ significantly. Such differences in the dual effects of level and volatility are explained precisely by the greater significance of the effect of volatility, which predominantly mitigates the effects of rising commodity prices. 


\begin{tabular}{|c|c|c|c|c|c|c|c|c|c|c|c|c|}
\hline \multirow{3}{*}{ 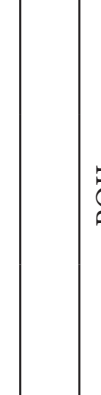 } & \multirow{3}{*}{ 言 } & $\bar{\Sigma}$ & $\begin{array}{l}0 \\
0 \\
0 \\
2 \\
0 \\
0\end{array}$ & 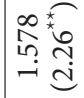 & 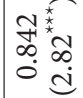 & 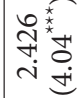 & 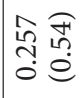 & 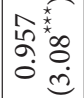 & 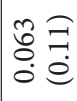 & & 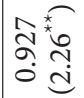 & $\begin{array}{l}a \\
0 \\
0 \\
m \\
m \\
m\end{array}$ \\
\hline & & $\varrho^{2}$ & 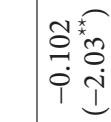 & 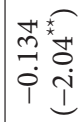 & (0) & 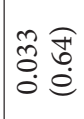 & $\begin{array}{ll}2 & \widehat{F} \\
0 & 0 \\
0 & 0 \\
1 & 1 \\
1 & 1\end{array}$ & 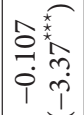 & 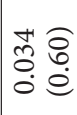 & & $\begin{array}{l}0 \\
0 \\
0 \\
0 \\
0 \\
0 \\
i \\
i\end{array}$ & 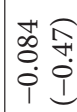 \\
\hline & & $\infty^{-1}$ & $\stackrel{\overbrace{}}{2}$ & 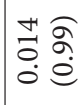 & 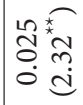 & 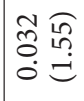 & 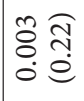 & 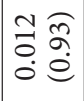 & ن. & & 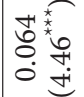 & 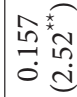 \\
\hline & \multirow{3}{*}{ 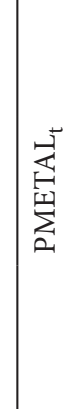 } & $\Sigma$ & 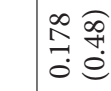 & 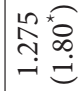 & I & 1 & 1 & 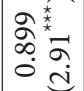 & 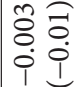 & & 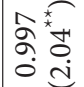 & $\begin{array}{l}q^{x} \infty \\
\dot{m}=\end{array}$ \\
\hline & & $\infty^{2}$ & 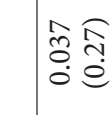 & 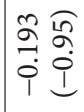 & 1 & 1 & 1 & 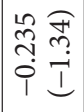 & 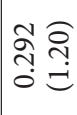 & & 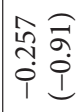 & ¿ำ \\
\hline $\begin{array}{l}\frac{n}{U} \\
z\end{array}$ & & $\infty^{-1}$ & 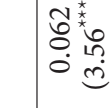 & 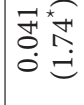 & 1 & 1 & 1 & 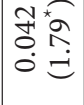 & 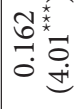 & & 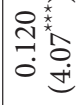 & 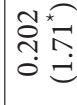 \\
\hline 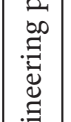 & \multirow{3}{*}{$\begin{array}{l}0 \\
0 \\
0 \\
0 \\
\text { L }\end{array}$} & 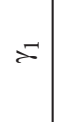 & 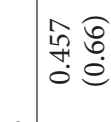 & 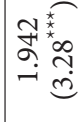 & 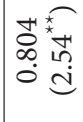 & 貉 & $\begin{array}{ll}\infty & \widehat{f} \\
0 & 0 \\
& 0 \\
0 & 0 \\
1 & 1\end{array}$ & 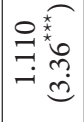 & 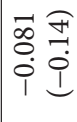 & $\stackrel{\mathscr{B}}{\Xi}$ & 䨔 & 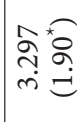 \\
\hline 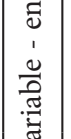 & & $\infty^{2}$ & 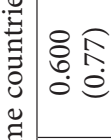 & 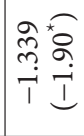 & $\begin{array}{ll}h & \widehat{\delta} \\
0 & 0 \\
0 & 0 \\
1 & 9\end{array}$ & 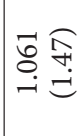 & 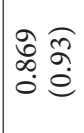 & 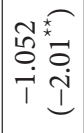 & 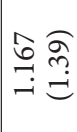 & 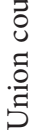 & 范 & 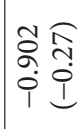 \\
\hline $\begin{array}{l}\vec{z} \\
\overrightarrow{\vec{v}} \\
\overrightarrow{\vec{v}} \\
\vec{v}\end{array}$ & & $\infty^{-1}$ & 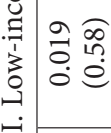 & 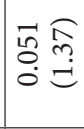 & 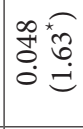 & 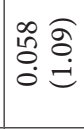 & 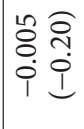 & 会 & 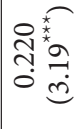 & 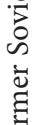 & 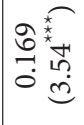 & 㕝 \\
\hline$\stackrel{\mathscr{I}}{E}$ & \multirow{3}{*}{ 莕 } & $\Sigma$ & 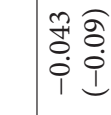 & 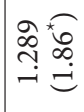 & 柋 & 稀 & 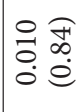 & 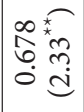 & $\begin{array}{ll}2 & \widehat{n} \\
0 & 0 \\
0 & 0 \\
1 & 1\end{array}$ & 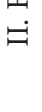 & 瓷 & 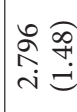 \\
\hline & & $\infty^{2}$ & 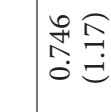 & 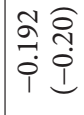 & 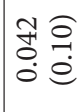 & 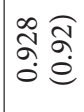 & \begin{tabular}{ll}
$\hat{b}$ & $\widehat{2}$ \\
\multirow{1}{1}{} & 0 \\
$i$ & 1 \\
1 & 1
\end{tabular} & 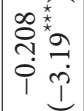 & 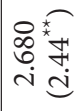 & & 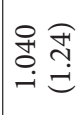 & 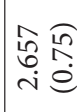 \\
\hline & & $\infty^{-1}$ & 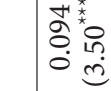 & 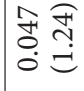 & 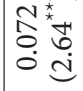 & 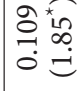 & 랑 & $\frac{m}{0} \stackrel{\frac{x}{x}}{0}$ & 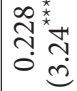 & & 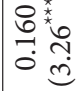 & $\begin{array}{l}\overrightarrow{\mathrm{N}} \\
\stackrel{2}{\Im}\end{array}$ \\
\hline & & $\Sigma$ & $\begin{array}{l}0 \\
0 \\
0 \\
0 \\
0 \\
0\end{array}$ & 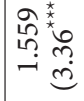 & 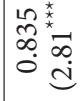 & 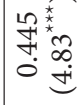 & $\begin{array}{ll}0 & 0 \\
0 & 0 \\
0 & 1 \\
1 & 1\end{array}$ & 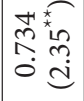 & 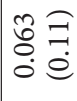 & & 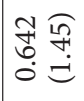 & 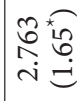 \\
\hline & 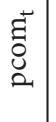 & $\infty^{2}$ & 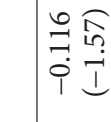 & 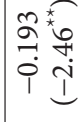 & 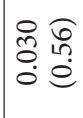 & 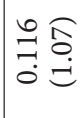 & 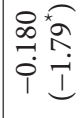 & 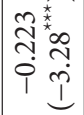 & 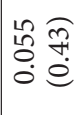 & & 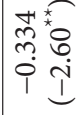 & $\begin{array}{ll}n & 0 \\
0 & 0 \\
1 & 0 \\
1 & 0\end{array}$ \\
\hline & & $\omega^{-1}$ & 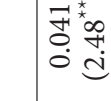 & $\mid \begin{array}{ll}\infty & 0 \\
0 & 0 \\
0 & 0 \\
0 & \stackrel{0}{e}\end{array}$ & 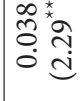 & 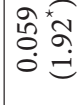 & 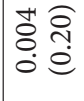 & 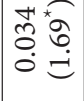 & 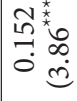 & & 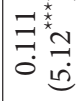 & 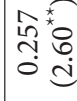 \\
\hline & $\begin{array}{l}\widehat{E} \\
\text { 章 }\end{array}$ & & 通 & 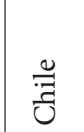 & $\begin{array}{l}\frac{\pi}{3} \\
\frac{\overrightarrow{0}}{0} \\
0\end{array}$ & 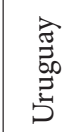 & 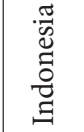 & 吾泀 & 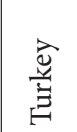 & & 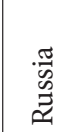 & 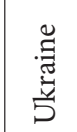 \\
\hline
\end{tabular}


Estimates for industrial production as a whole confirm the nature of functional dependencies for GDP dynamics, but there are certain differences. A more favorable dependence on world commodity prices appears in New Zealand, Mexico and Turkey. At the same time, the influence of price volatility is weakening in most countries, as was obtained for estimates of GDP.

The proposed impact assessment methodology includes indicators such as the commodity price index, agricultural raw materials, food products, metal prices, crude oil and, thanks to the use of Two-Step Least Squares (2SLS), can be used for any countries that want to evaluate and compare the impact of global commodities prices for the dynamics of GDP or the dynamics of industrial production, etc.

A study and analysis of the impact of world commodity prices on income dynamics in exporting countries of natural resources was carried out using the developed methodology. As a result of the study, we used a statistical model to assess the impact of world commodity prices on income dynamics.

The study is not without limitations. The proposed method should be further applied to developed countries that have a much higher level of export and are sensitive to changes in prices for one or another raw material.

\section{Author contributions}

The authors contributed equally.

\section{Disclosure statement}

The authors do not have any conflict of interest.

\section{References}

Aghion, P., \& Banerjee, A. (2005). Volatility and growth: the clarendon lectures in economics (160 p.). Oxford University Press. https://doi.org/10.1093/acprof:oso/9780199248612.001.0001

Araujo, R. (2016). Assessing the dynamics of terms of trade in a model of cumulative causation and structural change. Brazilian Journal of Political Economy, 36(1), 50-167. https://doi.org/10.1590/0101-31572016v36n01a09

Alcott, H., \& Keniston, D. (2016). Dutch disease or agglomeration? the local economic effects of natural resource booms in Modern America. Working Papers, 41 (73 p.). https://doi.org/10.2139/ssrn.2691500

Arezki, R., \& Nabli, M. K. (2012). Natural resources, volatility, and inclusive growth: perspectives from the Middle East and North Africa. IMF Working Paper 12/111 (25 p.). https://doi.org/10.5089/9781475503326.001

Auty, R. M. A (2001). Growth collapse with high rent point resources: Saudi Arabia. In R. M. Auty (eds.), Resource abundance and economic development (pp. 193-207). Lancaster University. https://doi.org/10.1093/0199275785.003.0012

Bacha, E., \& Fishlow, A. (2011). Recent commodity price boom and Latin American growth: more than new bottles for an old wine? In J. A. Ocampo \& J. Ros, The Oxford Handbook of Latin America Economics (pp. 394-400). Oxford Handbook. https://doi.org/10.1093/oxfordhb/9780199571048.013.0016
Bodart, V., Candelon, B., \& Carpantier, J.-F. (2012). Real exchanges rates in commodity producing countries: A reappraisal. Journal of International Money and Finance, 31, 1482-1502. https://doi.org/10.1016/j.jimonfin.2012.02.012

Brunnschweiler, C. (2008). Cursing the blessings? Natural resource abundance, institutions, and economic growth. World Development, 36(3), 399-419.

https://doi.org/10.1016/j.worlddev.2007.03.004

Butko, V. (2018). Not just the collapse of the lira: why is Turkey on the brink of financial crisis? Ukrainska Pravda (August 13). https://www.eurointegration.com.ua/experts/ 2018/08/13/7085547

Cakir, M. (2009, 14-15 November). Terms of trade and economic growth of emerging market economies. The International Conference on Administration and Business University of Bucharest (14 p.). University of Bucharest.

Carrere, C., \& Strauss-Kahn, V. (2012). Exports dynamics: raising developing countries exports survival though experince. Recherches the Development International, 21, 1-5.

Cavalcanti, T. de V., Mohaddes, K., \& Raissi, M. (2012). Commodity price volatility and the sources of growth. IMF Working Paper, WP/12/12 (43 p.). https://doi.org/10.2139/ssrn.1846429

Danilenko, L. N. (2014) The rent-commodity economy of Russia and problems of its transformation (Doctor's thesis). PGU.

Dovgan, D. (2015). Diversification of Ukrainian exports of ferrous metals and economic growth. Naukovyi visnyk Uzhhorodskogo Natsionalnogo Universytetu. Seriya: Mizhnarodni Economicni Vidnosyny ta Svitove Gospodarstvo, 3, 114-117.

Emara, N., Simutowe, A., \& Jamison, T. (2015). Commodity price changes and economic growth in developing countries. MPRA Paper, 68678 (17 p.). https://doi.org/10.15341/jbe(2155-7950)/10.06.2015/005

Fernández, A., Schmitt-Grohe, S., \& Uribe, M. (2017). World shocks, world prices, and business cycles: An empirical investigation. Journal of International Economics, 108, 2-14. https://doi.org/10.1016/j.jinteco.2017.01.001

Furman, V. (2018, May 18). Stimulating economic development: Turkey's experience and Ukrainian realities. Dzerkalo tyzhnia. https://dt.ua/gazeta/issue/1151

Gruss, B. (2014). After the boom-commodity prices and economic growth in Latin America and the Caribbean. IMF Working Paper, WP/14/154 (42 p.). https://doi.org/10.5089/9781498363518.001

Gylfason, T., Herbertsson, T., \& Zoega, G. (1999). A mixed blessing: natural resources and economic growth. Macroeconomic Dynamics, 3(02), 204-225. https://doi.org/10.1017/S1365100599011049

Hachula, M., \& Hoffmann, S. (2015). The output effects of commodity price volatility: evidence from exporting countries. Discussion Papers, 29 (33 p.).

Hossain, M., Haseen, L., \& Jabin, N. (2009). Dynamics and causality among exports, imports and income in Bangladesh. The Bangladesh Development Studies, 32(2), 101-113.

Houssa, R., Mohimont, J., \& Otrok, C. (2015). The sources of business cycles in a low income country. IMF Working Paper, WP/15/40 (33 p.). https://doi.org/10.5089/9781498310147.001

Ischuk, S., \& Tkach, S. (2020). Assessment of foreign trade prospects of Ukraine. Socio-economic Problems of the Modern Period, $15,12-17$.

Ito, K. (2012). The impact of oil price volatility on the macroeconomy in Russia. Annals of Regional Science, 48, 695-702. https://doi.org/10.1007/s00168-010-0417-1 
Jawaid, S. T., \& Raza, S. A. (2013). Effects of terms of trade on growth performance of India. Economic Modelling, 33(C), 940-946. https://doi.org/10.1016/j.econmod.2013.04.043

Jawaid, S. T., \& Waheed, A. (2011). Effects of terms of trade andits volatility on economic growth: a cross country empirical investigation. Transition Studies Review, 8(2), 217-229. https://doi.org/10.1007/s11300-011-0201-7

Kehoe, T. J., \& Ruhl, K. J. (2008). Are shocks to the terms of trade shocks to productivity? Review of Economic Dynamics, 11, 804-819. https://doi.org/10.1016/j.red.2008.04.001

Kose, M. (2002). Explaining business cycles in small open economies: how much do world prices matter? Journal of International Economy, 56(2), 299-327. https://doi.org/10.1016/S0022-1996(01)00120-9

Lederman, D., \& Maloney, W. F. (2007). Trade structure and growth. In D. Lederman \& W. F. Maloney (Eds.), Natural resources, neither curse nor destiny (372 p.). Stanford University Press. https://doi.org/10.1596/978-0-8213-6545-8

McGregor, T. (2017). Commodity price shocks, growth and structural transformation inflow-income countries. The Quarterly Review of Economics and Finance, 65, 285-303. https://doi.org/10.1016/j.qref.2017.01.006

Moreira, R. (2014). Commodities prices volatility, expected inflation and GDP levels: an application for a net-exporting economy. Procedia Economics and Finance, 14, 435-444. https://doi.org/10.1016/S2212-5671(14)00732-1

Nikonenko, U. (2014). Resource-dependent economy: conceptualization of the problem. Svit Finansiv, 1, 99-105.

Nikonenko, U. (2019). Macroeconomic determinants of the functioning of resource dependent economies in the context of globalization (monograph) (332 p.). Taras Soroka Publishing House.

Ploeg, van der F., \& Poelhekke, S. (2007). Volatility, financial development and the natural resource curse. EUI Working Papers, 36 (40 p.).

Perez Forero, F., \& Servan S. (2016). The dynamic response of the current account to commodity prices shocks in mining and non-mining exporting economies. Working Paper. Serie de Documentos de Trabajo. № 2016-012 (25 p.).

Poppe, K. (2016). Resource abundance and its impact on Latin American economic growth. Journal of Behavioural Economics, Finance, Entrepreneurship, Accounting and Transport, 4(3), 54-70.

Raddatz, C. (2007). Are external shocks responsible for the instability of output in low-income countries? Journal of Development Economics, 84, 155-187.

https://doi.org/10.1016/j.jdeveco.2006.11.001
Romero-Avila, D. (2009). Multiple breaks, terms of trade shocks and the unit-root hypothesis for African per Capita Real GDP. World Development, 37(6), 1051-1068.

https://doi.org/10.1016/j.worlddev.2008.09.005

Rosser, A. (2006) The political economy of the resource curse: a literature survey. IDS Working Paper, 268 (34 p.).

Sachs, J. D., \& Warner, A. M. (1995). Natural resource abundance and economic growth. NBER Working Paper, 5398 (47 p.). https://doi.org/10.3386/w5398

Sachs, J., \& Warner, A. (2001). Natural resources and economic development: the curse of natural resources. European Economic Review, 45, 827-838. https://doi.org/10.1016/S0014-2921(01)00125-8

Sandonato, S., \& Willebald, H. (2018). Natural capital, domestic product and proximate causes of economic growth: Uruguay in the long run. Sustainability, 10(715), 1870-2014. https://doi.org/10.3390/su10030715

Sylkin, O., Kryshtanovych, M., Zachepa, A., Bilous, S., \& Krasko, A. (2019). Modeling the process of applying anti-crisis management in the system of ensuring financial security of the enterprise. Business: Theory and Practice, 20, 446-455. https://doi.org/10.3846/btp.2019.41

Schmitt-Grohe, S., \& Uribe, M. (2018). How important are terms of trade shocks? International Economic Review, 59(1), 85111. https://doi.org/10.1111/iere.12263

Shousha, S. (2016). Macroeconomic effects of commodity booms and busts: the role of financial frictions (57 p.). Columbia University.

Trofimov, I. (2018). Income terms of trade and economic convergence: Evidence from Latin America. MPRA Paper, 87598 (30 p.).

UNCTAD. (2012). Excessive commodity price volatility: Macroeconomic effects on growth and policy options. Contribution from the UNCTAD secretariat to the G20 Commodity Markets Working Group (51 p.). https://unctad.org/en/Docs/gds_mdpb_G20_001_en.pdf

UNCTAD. (2016). The Trade and Development Report: Structural transformation for inclusive and sustained growth (252 p.). https://unctad.org/en/PublicationsLibrary/tdr2016_en.pdf

Vashkiv, O. (2017). Sectoral structural transformations in Ukraine in the context of post-industrial economic development. Globalni Ta Natsionalni Problemu Economiky, 16, 127-132. http://global-national.in.ua/archive/16-2017/27.pdf

Wong, H. T. (2004). Terms of trade and economic growth in Malaysia. Labuan Bulletin of International Business and Finance, 2(2), 105-122. 